\title{
The influence of coordination on the attention stability of children with different nervous system typologies
}

Georgiy Georgievich Polevoy Dotor en Educación Universidad Estatal de Vyatka. Kírov - Rusia g.g.polevoy@gmail.com http://orcid.org/oooo-0002-3300-3908

Artículo de Investigación

Recepción: 19 de enero de 2019 Aprobación: 30 de junio de 2019 https://doi.oig/10.19053/22160159.v10.n25.2019.9977

\section{Abstract}

The aim of the study is to define the influence of coordination abilities on attention stability development in first graders with different strengths of nervous system. Sixty 7- to 8-year-old schoolchildren from a usual comprehensive school participated in the research. Prior to the research, all children had been differentiated on equal 3 groups. The pedagogical experiment continued 7 months. During research there were changes in the groups. In the group $\mathrm{KG}$, in the Shuttle run test, indicators have worsened from $10,3 \pm 0,6 \mathrm{~s}$. to $10,4 \pm 0,6 \mathrm{~s} .(\mathrm{P}>0,05)$, and in the methodic Bourdon Test indicators have worsened on $0,1 \mathrm{p} .(\mathrm{P}>0,05)$. In the group EG-2, in which schoolchildren were engaged taking into account the nervous system typology, there were considerable and positive changes. In the Shuttle run test indicators have improved from 10,3 $\pm 0,6 \mathrm{~s}$. to $9,7 \pm 0,5 \mathrm{~s}$. $(\mathrm{P}<0,05)$, and in the methodic Bourdon Test indicators 
have improved on 1,4 p. $(\mathrm{P}<0,05)$. If the differentiated approach based on the typology is used, the indicators of movement coordination and attention stability will improve considerably during training.

Keywords: coordination abilities, differentiated approach, attention stability, types of nervous system, younger schoolchildren

\section{La influencia de la coordinación en la estabilidad de la atención de niños con diferentes tipologías de sistema nervioso}

\section{Resumen}

El propósito del estudio es definir la influencia de las habilidades de coordinación en el desarrollo de la estabilidad de la atención en estudiantes de primer grado con diferentes niveles de fuerza del sistema nervioso. 60 estudiantes entre los 7 y 8 años de escuela integral regular participaron en la investigación. Antes de la investigación, los niños fueron divididos en tres grupos iguales. El experimento pedagógico duró siete meses. Durante la investigación hubo cambios en los grupos. En el grupo KG, en el test Shuttle run, los indicadores empeoraron de 10,3 $\pm 0,6$ segundos a 10,4 $\pm 0,6$ segundos $(\mathrm{P}>0,05)$, asimismo, en el metódico Test Bourdon, los indicadores empeoraron en 0,1 puntos $(\mathrm{P}>0,05)$. En el grupo EG-2, en el cual los niños fueron agrupados según la tipología, hubo cambios positivos y considerables. En el test Shuttle run los indicadores mejoraron de 10,3 $\pm 0,6$ segundos a 9,7 $\pm 0,5$ segundos $(\mathrm{P}<0,05)$, asimismo, en el Test Bourdon, los indicadores mejoraron 1,4 puntos $(\mathrm{P}<0,05)$. Si se usa el enfoque diferenciado basado en la tipología, los indicadores de la coordinación del movimiento y de la estabilidad de la atención mejorarán considerablemente durante la formación.

Palabras clave: habilidades de coordinación, enfoque diferenciado, estabilidad de la atención, tipos de sistema nervioso, estudiantes de primeros grados

\section{L'influence de la coordination sur la stabilité de l'attention des enfants de différentes typologies du système nerveux}

\section{Résumé}

Le but de cette étude est de déterminer l'influence des capacités de coordination sur le développement de la stabilité de l'attention parmi des élèves 
du premier degré ayant des niveaux de force du système nerveux différents. Soixante élèves de 7 à 8 ans appartenant à l'école compréhensive régulière ont participé à la recherche. Avant la recherche, les enfants ont été divisés en trois groupes. L'expérience pédagogique a duré sept mois. Au cours de la recherche, il y a eu des changements dans les groupes. Pour le groupe KG, les indicateurs du Test Léger-navette ont révélé une régression de 10,3 $\pm 0,6$ secondes à 10,4 $\pm 0,6$ secondes $(\mathrm{P}>0,05)$, de même un Test de Bourdon méthodique a révélé une régression de 0,1 points $(\mathrm{P}>0,05)$. Dans le groupe $\mathrm{EG}-2$, où les élèves ont été groupés selon la typologie, il y a eu des changements positifs et significatifs. Dans ce cas, les indicateurs du Test Léger-navette ont révélé une amélioration de 10,3 $\pm 0,6$ secondes à $9,7 \pm 0,5$ secondes $(\mathrm{P}<0,05)$, de même le Test de Bourdon a révélé une amélioration de 1,4 points $(\mathrm{P}<0,05)$. L'adoption d'une approche différenciée basée sur la typologie permettrait d'améliorer significativement les indicateurs de coordination du mouvement ainsi que la stabilité de l'attention pendant leur formation.

Mots-clés : capacités de coordination, approche différenciée, stabilité de l'attention, types de systèmes nerveux, élèves des premiers degrés

\section{A influência da coordenação na estabilidade da atenção de crianças de diferentes tipologias do sistema nervoso}

\section{Resumo}

O propósito do estudo é definir a influência das habilidades de coordenação no desenvolvimento da estabilidade da atenção em estudantes de primeiro grau com diferentes níveis de força do sistema nervoso. Sessenta estudantes entre os 7 e 8 anos de escola compreensiva regular participaram na pesquisa. Antes da pesquisa, as crianças foram divididas em três grupos iguais. $\mathrm{O}$ experimento pedagógico durou sete meses. Durante a pesquisa houve mudanças nos grupos. No grupo KG, no teste Shuttle run, os indicadores pioraram de 10,3 $\pm 0,6$ segundos a 10,4 $\pm 0,6$ segundos $(\mathrm{P}>0,05)$, assim mesmo, num metódico Teste Bourdon, os indicadores pioraram em $\mathrm{O}, 1$ pontos $(\mathrm{P}>0,05)$. No grupo EG-2, no qual as crianças foram agrupadas segundo a tipologia, houve mudanças positivas e consideráveis. No teste Shuttle run os indicadores melhoraram de 10,3 $\pm 0,6$ segundos a

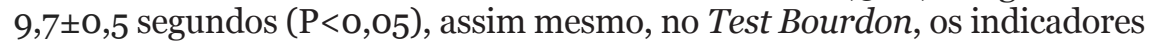
melhoraram 1,4 pontos $(\mathrm{P}<0,05)$. Usa-se $\mathrm{o}$ enfoque diferenciado baseado na tipologia, os indicadores da coordenação do movimento e a estabilidade da atenção melhorarão consideravelmente durante a formação.

Palavras-chave: habilidades de coordenação, enfoque diferenciado, estabilidade da atenção, tipos de sistema nervoso, estudantes de primeiros graus 


\section{Introduction}

In human life a large role is played by abilities and qualities, such as speed, strength, endurance, flexibility and others (Holodov \& Khuznetsov, 2009). A special value is allocated for coordination abilities (Issurin \& Lyakh, 2017; Sadowski, Wołosz, Zieliński, Niźnikowski, \& Buszta, 2015). The term coordination abilities appeared in the scientific world 60-70 years ago in order to concretize ideas about individual qualitatively different manifestations of human dexterity.

Every movement, simple or complex, is an interaction between the muscle and the central nervous system. This interaction can be defined as nervous and muscular coordination, which allows you to build control systems taking into account motor activity.

Coordination abilities-a kind of physical and motor abilities, which are based on the action of psychophysiological mechanisms that ensure the interaction of analyzers of the central nervous system and neuromuscular apparatus, and concretize the idea of motor qualities of agility-have a genetic basis in the form of complex anatomical and physiological inclinations that determine the special motor capabilities of a person:

1) Level of development and correlation of signal systems. Natural properties of analyzers: visual, auditory, muscular-motor sensations.

2) Properties of the nervous system: strength, balance, mobility, dynamism, plasticity, lability.

3) Separate levels of the central nervous system. Levels of construction of movement. Unevenness of their development cause different coordination abilities shown at the solution of various motive tasks.

Well-developed movement coordination in children-from early childhood-allows them to quickly improve their technical skills in all sports. Coordinated children are easier to perform different exercises, not only in physical culture or training, but also in everyday life. Person's coordination abilities are his abilities to quickly, precisely, and economically carry out motive tasks, 
especially those difficult and unexpectedly arisen (Holodov \& Khuznetsov, 2009). Despite the variety of coordination abilities, there is an exact classification of them that defines the general, special and specific ones. Besides, general coordination abilities are the bases for development of all other abilities (Alexandrova \& Shian, 2014; Dveyrina, 2014). The favorable period for development of the general coordination abilities is the earlier school age (Feoktistov, 2010; Ljach \& Witkowski, 2010).

About communication of mental and physical abilities, there are some researches (Greig, Marchant, Lovell, Clough, \& McNaughton, 2007; Shawkat, 2014; Vespalec, Zhu, \&Zvonar, 2014). It is necessary to refer to the main mental processes: memory, thinking, attention, and some other. Attention properties also have a classification: stability, switching, distribution, concentration, and others. Separately, it is necessary to talk about children's ability to steady attention. Attention stability is the duration of drawing attention to the same object or to the same task. It is especially necessary in the conditions of monotonous work when the same actions are carried out for a long time. Schoolchildren's work quality depends on attention stability. Training consists of different materials which are studied in a consecutive order. If schoolchildren can keep stability for 10-15 minutes, then they acquire only a part of information. Attention stability is also necessary in other kinds of activity, for example, in sports. In game sports, such as soccer, basketball, or hockey it is important to keep attention stability throughout all game. The absence or slackness at some point can lead you to be defeated in wrestling (Furley \& Memmert, 2015; Nemov, 2003).

One of the major aspects when training children is the use of the differentiated approach. Such approach realizes children's potential and abilities (Bakulev, Dveyrina, \& Savvina, 2006; Santos et al., 2018).

Currently, sport achievements largely depend on how fully implemented the potential of the athlete is in the conditions of preparation for competitive activity, which are due to their individual characteristics. One of the most important coach's pedagogical tasks is to study the individual identity of his pupil's body and personality, in order to find adequate means and methods of training and teaching. Today, up to $70-80 \%$ of the teaching loads 
have group and team nature, and the same load cannot be optimal for everyone. Therefore, currently, more and more attention is paid both to the coach's individualization and to learning process and sports training differentiation. Individualization of training athletes to fully disclose their abilities contributes to a more rapid growth of sports results. Today in teaching, the principle of individualization is more nuanced approach than the individual one.

The differentiated approach is a method of association of athletes in educational and training groups taking into account their sport important qualities. It uses for each group certain ways of training adequate to their typical features, such as sex, age, temperament properties, level of fitness, etc. The differentiated approach means process of training and education which assumes complex studying and the account of pupils' individual features. They are distributed in groups and their work organization is based on specific educational tasks performance.

One effective criterion of differentiation of children in groups is the typology of nervous system, which is understood as features of manifestation of properties of nervous system. One of such properties is force of nervous system on excitement process typology (Drozdovski, 2015; Kostyunina, Kiryanova, \& Anisimova, 2010; Serova \& Voronov, 2013).

At the same time, Pavlov (1951) created the doctrine of the basic properties of the human nervous system as the leading parameters of its functional organization. Under the force of nervous processes, he understood the nerve cells performance, namely, their ability to endure severe stress without falling into a braking state-exorbitant inhibition.

The main properties of the nervous system, according to Pavlov (1951), include:

1) Nervous system power: the power of processes of excitation and inhibition. The cerebral cortex cells performance-their endurance-depends on this property. At the same time, it distinguishes the strength and weakness of the nervous processes:

a) The strength of the nervous processes is characterized by efficiency. It endurances the nervous system and manifests itself 
in the ability to tolerate prolonged or short-term, but very strong, excitation or inhibition.

b) The weakness of nervous processes is the inability of nerve cells to withstand prolonged and concentrated excitation or inhibition.

2) Mobility of nervous processes: speed of change of excitation by braking, and vice versa. According to this property of nervous system in different people, the differences are manifested especially vividly.

3) Nervous system balance: the measure of strength of excitation or strength of inhibition. The property of balance of different people manifests itself in different ways, for example, often the braking process lags behind in its strength from the excitatory process.

It is noted that a strong nervous system [SNS] can solve better some problems; a weak nervous system [WNS] can solve better others. To solve the same problem, a WNS and a SNS go different ways.

Currently, the accumulated material clarifies the WNS features. WNS has high reactivity-sensitivity. As a result of increased reactivity of nerve cells, it quickly consumes the stock of functional substances. However, with a properly organized work and rest mode, the stock of reactive material is continuously restored, so that the WNS high productivity can be ensured.

It is known that tennis players with WNS are resistant to the emergence of a mental state of monotony. Knowledge of the identified features in the dynamics of the results growth rate in accordance with the individual's characteristics will allow both to predict the results more realistically and to plan more purposefully the long-term training process of young players. Features of manifestation of nervous system properties act in the form of inclinations to some abilities, strong-willed qualities, and resistance to adverse conditions. The weaker the nervous system, the greater the resistance to monotony a person possesses. People with SNS have a higher ability to concentrate, and those with WNS have a higher ability to distribute attention.

Jumpers with SNS need to perform a greater number of hops. They require longer recovery technical training. Athletes who 
are dominated by the process of excitement quickly concentrate before the jump. They also need a short pause between attempts. It is established that people with SNS are able to maintain a given level of intensity for a longer period of time, while those with WNS function more effectively in a short period of time. Power and speedpower abilities significantly change in athletes with WNS after volume loading, while for those with SNS, intensity is more effective than volume loading. There are different capabilities identified, which differ from person to person according to the strengths and weaknesses of the nervous system by the process of excitation. People with SNS are able to effectively overcome the feeling of fatigue. They show the ability to keep on moving. People with WNS quickly and successfully perform monotonous work. People with a WNS quickly master the complex technical elements, while people with a SNS manifest themselves better in competitive conditions.

People with WNS are more sensitive and able to work with high intensity from the very beginning. In the conditions of switching from work to rest, the advantaged are those with a SNS.

In the process of excitation, people with WNS conduct more actively the first part of the session, while those with SNS show uniformity in the training session, with some increase of activity at the final part of the session. The duration of rest between the approaches for people with WNS, at the beginning of the lesson is insignificant, but as fatigue occurs the rest time should be increased. For people with SNS, a long rest period in the first part of the lesson is explained by the process of working out. Great endurance allows them to carry out the entire training with high activity, while the recovery time and the duration of rest pauses remains unchanged. The ability to master the motor actions of athletes with different characteristics in the same conditions is manifested differently. In the conducted pedagogical experiments, the orientation of classes was regulated: the volume and intensity of the training load varied. At the initial stage of training, difficultcoordination exercises were assigned to gymnasts with a SNS for no more than 10 minutes of training, and to gymnasts with a WNS for a period of time between 10 and 15 minutes. When performing exercises aimed at the development of dynamic balance, it is recommended 1012 repetitions of one exercise with a rest interval of 12-15 seconds for gymnasts with a WNS, and 6-8 reps with a rest interval of 8-10 seconds for gymnasts with a SNS. For the first ones it is more expedient to 
increase the number of series and rest intervals. The authors note that the optimality of training loads-intensity or volume-depends on the properties of the nervous system power. Thus, for people with WNS, the greatest training effect will be obtained by using a volume load, and for people with SNS, by intensity. Tennis players' training conducted without taking into account individual abilities significantly inhibits the growth of sport skills. Athlete's speed is determined by a WNS, while and patience is determined by a SNS.

Thus, the individual approach is mainly used in high-class athletes' training, but the existing principle of individualization in pedagogy reflects a more differentiated approach than the individual.

There is no doubt about the need of using the differentiated approach in young athletes' educational and training process. This approach, of course, increases training effectiveness. Optimizing the learning process is one of the most effective ways to use the hidden reserves of the human body. Training process differentiation is one form of players' training management, which is based on the consideration of athletes' specific characteristics in the planning of the load.

The aim of the study is to define the influence of coordination abilities on attention stability development in physical culture classes with first graders with a different nervous system force.

The research hypothesis is the assumption that differentiated coordination training not only will improve indicators of schoolchildren's movement coordination, but also will improve indicators of attention stability, especially those of children who are engaged in physical culture, taking into account their nervous system force.

\section{Methods}

7- to 8-year-old schoolchildren who have been healthy and allowed in physical culture classes participated in the research. They have been differentiated in three equal groups of 60 boys and girls (Sklyar, 2015):

- First group [KG]: schoolchildren were engaged according to the standard program for the first class (Lyakh \& Zdanevich, 2010). 
- Second group [EG-1]: schoolchildren were engaged according to the standard program (Lyakh \& Zdanevich, 2010), but after warm-up they carried out exercises on coordination abilities development for 12-15 minutes (Holodov \& Khuznetsov, 2009).

- Third group [EG-2]: children were engaged according to the standard program (Lyakh \& Zdanevich, 2010), but at the beginning of the training they carried out exercises on coordination abilities development, taking into account their differentiation in subgroups by the typological criterionnervous system force. The main difference of trainings in EG-2 was the fact that schoolchildren carried out physical exercises with different loading. For schoolchildren with SNS this loading was more intensive, and for children with WNS loading had more volume. As a rule, the loading volume increased as repetitions and rest time increased. Intensity increased as the exercises amount increased and rest time decreased (Drozdovski, 2015; Kostyunina et al., 2010; Polevoy, 2017, 2018; Serova \& Voronov, 2013).

During the pedagogical experiment, 59 trainings have been given in physical culture. Each training lasted 45 minutes. Trainings took place twice a week.

For coordination abilities development, simple physical exercises, such as run, jumps, somersaults, and exercises with objects-a ball, a jump rope, a stick-were used. In trainings the repetition method was used when children studied new exercises. The variable method was applied after exercise studying, at the same time.

1) Standard re-exercise method is used when there is new learning or in coordination with complex motor actions.

2) Variable exercise method is the main method in the athlete's coordination abilities development.

3) Game method opens up broad prospects for students to show independence, initiative, resourcefulness, determination, and perseverance.

4) Competitive method is used in control, friendly and calendar 
games. Individual exercises are also held in the form of competitions, for example: who will hit the target more precisely? Who controls the ball more effectively on a certain segment?

For the schoolchildren's coordination abilities development, it is recommended to use the following methods:

1) Introduction of new exercises.

2) Complexity of the previously learned exercises, new-source application, and movements pace increase.

3) Reducing the space for the exercise.

4) Juggling objects.

5) Introduction to the exercise of several balls.

6) Variation of tactical conditions.

7) Use of equipment and sites of different quality.

8) Creating an unusual execution speed with the help of simulators.

The stress components that must be considered when planning the work with the sportsmen from different disciplines, aimed at the development of coordination abilities, are:

1. Movement complexity: For the coordination abilities development, exercises of varying degrees of complexity are used, but the most effective version of the work is noted in the range of $75-90 \%$ of the maximum level. In this case, a sufficiently large total amount of work is provided, contributing to coordination abilities development. For young athletes, as the author emphasizes, tasks with relatively low-40-60\%-and moderate-60-75\%coordination complexity are more effective.

2. Work intensity: The initial stages of coordination abilities development are characterized by low intensity, then, with the athlete's technical expansion and tactical capabilities, intensity gradually increases. Near-limit and limit intensity is used when it comes to improving coordination abilities. 
3. Exercise duration: This component of the load depends mainly on the task facing the person. If the exercise and the work intensity are already determined-for example, balance on one leg or running with obstacles at a specific distance-the duration of the work is typically 10-20 s. The work is completed before the onset of fatigue.

4. Number of repetitions of one exercise: At short work in each exercise the amount of repetitions should be from 6 to 10-12. With longer tasks the number of repetitions decreases and should not exceed 2-3.

5. Duration and nature of pauses between exercises: With the coordination abilities development, the pauses between exercises are quite large-from 1 to 2-3 minutes. They should ensure the efficiency restoration, as well as psychological adjustment of those engaged in the effective performance of the subsequent task. In some cases, when the task is to perform work in conditions of fatigue, pauses can be significantly reduced-sometimes up to 1015 seconds. This ensures the work performance in conditions of progressive fatigue. The nature of the rest between exercises is active or passive.

The exercises complexity increased due to change of objects weight, their arrangement, height, change of external conditions, use of combinations of run with jumps and so on. On finishing, a stage game and competitive methods were used (Holodov \& Khuznetsov, 2009).

Prior to the beginning and after the end of the research all schoolchildren took tests. Attention stability was determined by a methodic Bourdon test (Book \& Shirn, 1997). Nervous system force was determined by a methodic Tapping test (Raigorodskiy, 2017). The level of coordination abilities development was determined by the Shuttle run 3x10 test (Lyakh \& Zdanevich, 2010). Results of indicators have been processed with help of T-Student.

\section{The Bourdon Test.}

On the sheet of paper numbers in any order are represented (table 1). 
Table 1

Fragment of the form to perform the Bourdon Test

\begin{abstract}
35679865243561956428376494653824659837645825376 94685421356897546833764986752435689754316528679 46538727656536426265654848979876321534564979879 856424332463216395975975975468337649867524356897 54316528679465387276565364262656548489798763215 34564979879856424332463216395975975134685764956 82435679865243561956428376494653824659837645825 37694685421356897561297468337649867524356897543 16528679465387276565364262656548489798763215345 649798798564243324632163959759756335679865243561 95642837649465382465983764582537694685421356897 54683376498675243568975431652867946538727656536 426265654848979876321534564979879856424332463
\end{abstract}

Adapted from Book \& Shirn (1997).

On command "Go" within 2,5 min the schoolchildren have to cross out certain number, for example " 4 ".

The result is determined by the formula $S=(0,5 \mathrm{~N}-2,8 \mathrm{n}) / \mathrm{t}$.

S: indicator of attention stability.

$\mathrm{N}$ : quantity of the numbers checked for operating time.

t: operating time.

$\mathrm{n}$ : quantity of the mistakes made for operating time-the missed necessary or crossed-out unnecessary numbers.

Chart with indicators

S - 0,25 points each

$\mathrm{t}$ - each 30 sec.

5 points: The line does not go beyond one zone-an excellent indicator of attention stability. 
4 points: The line does not go beyond two zones.

3 points: The line does not go beyond three zones.

2 points: The line does not go beyond four zones.

1 point: The line does not go beyond five zones.

\section{The Shuttle run $3 x 10$ test.}

The start line and the finish line are $10 \mathrm{~m}$ away from each other. At the command of "Go" children run from start to the finish and touch the line by hand, then they come back to the start line and touch it by a hand, and carry out the last acceleration towards the finish line.

The result is the time spent on solving the mission $(0,1 \mathrm{~s})$.

\section{The Tapping-test.}

On the A4 sheet of paper 6 squares, 3 from above and 3 from below are lined. At the command of "Go", children put dots in each square at maximum speed. 5 seconds are allotted on one square. Then on command "Transition", exercise continues in other square.

The result is the total number of points in each square. The number of points is plotted. The graph shows the strength of the nervous system in the process of excitation.

For mathematical and statistical processing of results the parametrical criterion T-Student was used. The result was significant at $\mathrm{P}>0,05$. The correlation analysis was made with use of the Biostat-2009 program (David \& Cramer, 1947; Oldham, 1993).

\section{Results}

Prior to the pedagogical experiment in all groups, average values of coordination abilities in the Shuttle run test were approximately identical $(\mathrm{P}>0,05)$. Children in EG-2 have been differentiated on 2 subgroups taking into account typology. After the pedagogical experiment new results of the research (table 2) have been received. 
Table 2

Change of indicators the coordination abilities and stability of attention in 7- to 8-year-old schoolchildren $(M \pm m)$

\begin{tabular}{ccccc}
\hline Indicators & Group & Before & After & P \\
\hline \multirow{3}{*}{ Shuttle run 3x10 m (second) } & KG & $10.3 \pm 0.6$ & $10.4 \pm 0.6$ & $>0,05$ \\
& EG-1 & $10.3 \pm 0.6$ & $10.1 \pm 0.5$ & $>0,05$ \\
& EG-2 & $10.3 \pm 0.6$ & $9.7 \pm 0.5$ & $<\mathbf{0 , 0 5}$ \\
\hline \multirow{3}{*}{ Test Bourdon (points) } & KG & $3.4 \pm 0.3$ & $3.3 \pm 0.4$ & $>0,05$ \\
& EG-1 & $3.3 \pm 0.2$ & $3.6 \pm 0.3$ & $>0,05$ \\
& EG-2 & $3.1 \pm 0.4$ & $4.5 \pm 0.3$ & $<\mathbf{0 , 0 5}$ \\
\hline
\end{tabular}

The analysis of table 2 shows that during the pedagogical experiment in both tests and in all indicators there were changes.

In $\mathrm{KG}$, in which schoolchildren were engaged to the standard program, indicators were the worst in both tests. In the Shuttle run test, indicators have worsened from $10,3 \pm 0,6 \mathrm{~s}$. to 10,4 $\pm 0,6 \mathrm{~s}$. $(\mathrm{P}>0,05)$, and in the Bourdon test, indicators have worsened on 0,1 p. $(\mathrm{P}>0,05)$.

In EG-1, in which children were engaged according to the standard program, but, at the same time, carried out coordination exercises, there were positive changes in both tests. In the Shuttle run test, indicators have improved from $10,3 \pm 0,6 \mathrm{~s}$. to $10,1 \pm 0,5 \mathrm{~s}$. $(\mathrm{P}>0,05)$, and in the Bourdon test, indicators have improved on 0,3 p. $(\mathrm{P}>0,05)$.

In EG-2, in which schoolchildren were engaged in the differentiated coordination training taking into account typology, there were considerable and positive changes in both indicators. In the Shuttle run test, indicators have improved from 10,3 $\pm 0,6 \mathrm{~s}$. to $9,7 \pm 0,5$ s. $(\mathrm{P}<0,05)$, and in in the Bourdon test, indicators have improved on $1,4 \mathrm{p} .(\mathrm{P}<0,05)$.

\section{Discussion}

Certainly, in the person's activity his abilities play a large role. Despite their variety, all of them perform different functions and, as a rule, interact among themselves. Some of the major abilities are coordination indicators, especially the general ones which are 
the base for development of other coordination abilities (Issurin \& Lyakh, 2017; Sadowski et al., 2015).

There are no doubts that the general coordination abilities are developed more intensively at earlier school age (Feoktistov, 2010; Ljach \& Witkowski, 2010). In our research it was confirmed.

In spite of the fact that we did not manage to find data which show influence of coordination abilities on schoolchildren attention stability, in a new research we managed to establish it. Actually, if the level of coordination abilities development is higher, the indicators of children's attention stability are higher, that is to say, the interrelation of mental processes and physical abilities is established, which is confirmed by earlier conducted researches (Greig et al., 2007; Shawkat, 2014; Vespalec et al., 2014).

Among variety of mental processes, separately attention stability should be noted. For a long time, a person can be focused on any subject. Attention stability is defined by type of nervous system, temperament, motivation-novelty, the importance of requirement, and personal interests-and also external conditions of the person's activity (Nemov, 2003; Furley \& Memmert, 2015).

The use of the differentiated approach on occupations with children-especially, with the younger ones at school age-is the most important catalyst of realization of their internal resources (Bakulev et al., 2006; Santos et al., 2018). In the theory and practice of work with children there are different criteria by which schoolchildren can be differentiated in groups, for example, on the basis of age, sex, temperament type, physical and technical training, and many other indicators (Holienka, Babic, Doležajová, Šelinger, \& Musilová, 2017; Ion, Serghei, \& Constantin, 2018; Shakhanova, Chelyshkova, Kuzmin, Silantyev, \& Grechishkina, 2016). One of the effective criteria for schoolchildren differentiation in groups is the typological criterion, namely, nervous system force on excitement process.

Results of the pedagogical experiment confirm earlier obtained data of other researches on efficiency of use of typological criterion of children differentiation in groups (Drozdovski, 2015; Makarov \& Hussain, 2011; Serova \& Voronov, 2013). The efficiency of use of 
different loading in physical culture classes for children who have different nervous system force on excitement process is proved. It is important to emphasize that intensive loading will be more effective for development of coordination abilities of children with SNS; at the same time, for children with WNS use of volume loading will be more effective (Polevoy, 2017, 2018).

Influence of coordination abilities on attention stability development in physical culture classes at school with first graders with a different nervous system force has been for the first time defined. Thus, after the end of the pedagogical experiment, the research hypothesis has been solved and the purpose has been achieved.

If at the beginning of each physical culture class with 7 - to 8-year-old children physical exercises on coordination abilities development are carried out, then schoolchildren indicators of movement coordination and indicators of attention stability will improve, especially for those who are engaged and differentiated according to the typological criterion.

\section{Conclusion}

Results of the research allow revealing several important conclusions. On each physical culture class it is necessary to allot 12-15 minutes for children's coordination abilities development. Using the differentiated approach and the different loading for children based on typology of nervous system, coordination abilities indicators and attention stability will be improved considerably.

The results of the research can be useful to teachers, trainers, and athletes. These results are an absolute new perspective for further studying of a problem of interrelation of mental processes and children's physical abilities.

\section{References}

Alexandrova, V., \& Shian, V. (2014). Some types of the coordination abilities of the athlete-dancers. Uchenye zapiski universiteta imeni P.F. Lesgafta, 112(6), 12-17. https://doi.org/10.5930/issn.19944683.2014.06.112.p12-17 
Bakulev, S., Dveyrina, O., \& Savvina, A. (2006). Differentiated approach to the determination of major sports coordination abilities boxer. Uchenye zapiski universiteta imeni P.F. Lesgafta, 20, 3-9. https:// doi.org/10.5930/issn.1994-4683.2006.20.p3-9

Book, J., \& Shirn C. (1997). Almanac of psychological tests. Moscow: KSP

David, F., \& Cramer H. (1947). Mathematical methods of statistics. Biometrika, 3-4(34), 374. https://doi.org/10.2307/2332454

Drozdovski, A. (2015). The connection between typological complexes of properties of the nervous system, temperaments, and personality types in the professions and sports. Open access journal of sports medicine, 6, 72-161. doi:10.2147/OAJSM.S75612

Feoktistov, M. (2010). Periods of sensitivity of development of physical abilities among various contingents of pupils at average school age. Uchenye zapiski universiteta imeni P.F. Lesgafta, 62(4), 118-120. http://doi.org/10.5930/1994-4683.2010.04.62.p118-120

Furley, P., \& Memmert, D. (2015). Creativity and working memory capacity in sports: working memory capacity is not a limiting factor in creative decision making amongst skilled performers. Movement Science and Sport Psychology, 6, 115. doi: 10.3389/fpsyg.2015.00115

Greig, M., Marchant, D., Lovell, R., Clough, P., \& McNaughton, L. (2007). A continuous mental task decreases the physiological response to soccer-specific intermittent exercise. British Journal of Sports Medicine, 41(12), 908-913. doi: 10.1136/bjsm.2006.030387

Holienka, M., Babic, M., Doležajová, L., Šelinger, P., \& Musilová, E. (2017). Motor performance of young soccer players based on their biological age. Journal of Physical Education and Sport, 17(4), 2508-2512.

Holodov, Z., \& Khuznetsov, V. (2009). Theory and methodics of physical training and sports. Moscow: Akademia.

Ion, C., Serghei, S., \& Constantin, C. (2018). Differentiated physical training within the framework of a yearly training cycle of young footballers specialized on the position of goalkeeper. Journal of Physical Education and Sport, 18(1), 270-275.

Issurin, V., \& Lyakh, V. (2017). Coordination abilities of athletes: basics of manifestation, evaluation and elucidation: a review. Journal of athletic enhancement, 6, 2. https://doi.org/10.4172/2324-9080.1000255 
Kostyunina, L., Kiryanova, L., \& Anisimova, Y. (2010). Special features of the manifestation of nervous system typological properties among sprint track and field athletes. Uchenye zapiski universiteta imeni P.F. Lesgafta, 62, 38-42.

Ljach, W., \& Witkowski, Z. (2010). Development and training of coordination skills in 11- to 19-year-old soccer players. Human physiology, 1, 64-71. https://doi.org/10.1134/s0362119710010081

Lyakh, V., \& Zdanevich, A. (2010). Work program on physical culture, grade 1-4. Moscow: Education.

Makarov, Y., \& Hussain, A. (2011). Typological profile of person properties of the basketball players aged 16-18 years old depending on the style of game activity. Uchenye zapiski universiteta imeni P.F. Lesgafta, $73,122-124$.

Nemov, R. (2003). Psychology. Psychodiagnostics. Introduction to scientific psychological research with elements of mathematical statistics. Moscow: Vlados.

Oldham, J. (1993). Statistical tests (Part 2): parametric tests. Nursing standard, 44, 28-30. https://doi.org/10.7748/ns.7.44.28.s54

Pavlov, I.P. (1951). Complete works. Moscow: KSP

Polevoy, G. (2017). The spatial orientation of the players with different type of nervous system. International Journal of Applied Exercise Physiology, 6(4), 1-6. doi: https://doi.org/10.22631/ijaep.v6i4.175

Polevoy, G. (2018). The Development of the Ability to Equilibrium Football players 10-11 years with different Nervous System. Journal of Medical and Health Sciences, 12(1), 496-499.

Raigorodskiy, D. (2017). Practical psychodiagnostics. Methodics and tests. Samara: Bakhrakh-M.

Sadowski, J., Wołosz, P., Zieliński, J., Niźnikowski, T., \& Buszta M. (2015). Structure of coordination motor abilities in male basketball players at different levels of competition. Polish journal of sport and tourism, 21(4), 234-239. https://doi.org/10.1515/pjst-2015-0004

Santos, S., Coutinho, D., Gonçalves, B., Schöllhorn, W., Sampaio, J., \& Leite, N. (2018). Differential Learning as a Key Training Approach to Improve Creative and Tactical Behavior in Soccer. 
Research Quarterly for Exercise and Sport, 89(1), 11-24. doi: 10.1080/02701367.2017.1412063

Serova, L., \& Voronov, A. (2013). Dependence of individual style of activity in table tennis on typological properties of the identity of athletes. Uchenye zapiski universiteta imeni P.F. Lesgafta, 95, 140-143. https://doi.org/10.5930/1994-4683.2013.01.95.p140-143

Shakhanova, A., Chelyshkova, T., Kuzmin, A., Silantyev, M., \& Grechishkina, S. (2016). Effect of team sports on aerobic performance of human body in view of somatotype. Indian Journal of Science and Technology, 9(42). doi: 10.17485/ijst/2016/v9i42/104257

Shawkat, R. (2014). The impact of development of the special coordination abilities on the general skill ability for table tennis juniors under 12 years old. International journal of science culture and sport, 4(2), 30-42. https://doi.org/10.14486/ijscs71

Sklyar, V. (2015). Usage of statistical methods in the pedagogical researches. Science Rise, 5(17), 39-43. https://doi.org/10.15587/23138416.2015 .57049

Vespalec, T., Zhu, W., \& Zvonar, M. (2014). Relationship between physical activity and coordination: a middle-age adult study. Medicine \& science in sports \& exercise, 46(5S), 770. doi: 10.1249/01. mss.0000495808.88582.1f 